\title{
APE 2015 Program Committee
}

Mayur Amin, Senior Vice President of Research, Elsevier, Oxford

Grace Baynes, Corporate Public Relations, Nature Publishing Group, London

Dr. Anke Beck, President Publishing, De Gruyter, Berlin

Dr. Georg W. Botz, Open Access Policy, Max-Planck-Gesellschaft, Munich

Dr. Jan Brase, Head of DataCite, German National Library of Science and Technology (TIB), Hannover

Sabine Brünger-Weiland, President \& CEO, FIZ Karlsruhe, Leibniz Institute for Information Infrastructure, Eggenstein-Leopoldshafen

Dr. Jacques Bus, Secretary General of Digital Enlightenment Forum, The Hague

Robert C. Campbell, Senior Publisher, Wiley-Blackwell, Oxford

Dr. H. Frederick Dylla, Executive Director and CEO, American Institute of Physics, College Park, MD

Dr. Einar Fredriksson, Director, IOS Press, Amsterdam

Herbert Gruttemeier, Head International Relations, INIST-CNRS, Vandoeuvre-lès-Nancy

Stuart Hamilton, Senior Policy Advisor, IFLA, The Hague

Prof. Dr. Pascal Hitzler, Knowledge Engineering Lab, Kno.e.sis, Ohio Center of Excellence in Knowledge-enabled Computing, Wright State University, Dayton, OH

Reinhard Karger, President, German Society for Information and Knowledge (DGI), Frankfurt am Main \& Company Spokesman, German Research Center for Artificial Intelligence (DFKI) Saarbrücken

Arnoud de Kemp, Co-Editor-in-Chief of "Information Services \& Use" \& Publisher, Akademische Verlagsgesellschaft AKA, Berlin

Prof. Dr. Wolfram Koch, Executive Director, German Chemical Society, Frankfurt am Main

Ulrich Korwitz, Director, German National Medical Library, Cologne

Tony Llewellyn, Executive Director, International Council for Scientific and Technical Information (ICSTI), Paris

Michael Mabe, CEO, International Association of Scientific, Technical and Medical Publishers (STM), The Hague and Oxford

Dr. Salvatore Mele, Head of Open Access, CERN, Geneva

Dr. Wolfram Neubauer, Director, ETH Libraries and Collections, Zurich

Dr. Bernd Pulverer, Chief Editor, Head of Scientific Publications, The EMBO Journal, EMBO, Heidelberg

Dr. Georg Rehm, Head, German/Austrian W3C Office, DFKI Language Technology Lab, Berlin

Ian Russell, Editorial Director, Science, Oxford University Press, Oxford

Prof. Dr. Bernhard Sabel, Editor-in-Chief, "Restorative Neurology and Neuroscience", Medical Faculty, Otto-v.-Guericke Universität, Magdeburg

Dr. Ralf Schimmer, Head, Max Planck Digital Library (MPDL), Max-Planck-Gesellschaft, Munich

Dr. Eefke Smit, Director, Standards and Technology, International Association of Scientific, Medical and Technical Publishers (STM) 
Prof. Dr. Christian Sprang, Legal Counsel, German Association of Publishers and Booksellers (Börsenverein), Frankfurt am Main

Wim van der Stelt, Vice President Publishing Strategy, Springer, Doetinchem

Dr. Els van Eijck van Heslinga, Acting Director of Finance and Corporate Services, National Library of The Netherlands, The Hague

Jan Velterop, Advocate and Advisor, Open Access and Open Science, Surrey

Dr. Eva Wille, VP, Executive Global Director Chemistry, Wiley-VCH, Weinheim

Ir Wilma von Wezenbeek, Director, TU Delft Library, Delft 